\title{
SALÁRIO-EDUCAÇÃO: UM MECANISMO DE FINANCIAMENTO
}

\section{EDUCATION SALARY: A FINANCING PATH OF BRAZILIAN EDUCATION}

\author{
Carlos Roberto Jamil Cury \\ Pontifícia Universidade Católica de Minas Gerais - PUC Minas
}

Genuino Bordignon

Universidade de Brasília - UnB

\section{RESUMO:}

Este artigo pretende historiar a chegada do salário-educação ao ordenamento jurídico nacional e sua evolução posterior, com suas mudanças. Como mecanismo de financiamento da educação escolar brasileira, ele se acopla a outros mecanismos, sobretudo, os constitucionais de financiamento da educação. Como tal, esse mecanismo tornou-se importante para o direito à educação, já que se impõe como uma forma de colaboração da sociedade no financiamento da educação e, no caso das empresas privadas, na função social da propriedade. Esse artigo se apoia em documentos históricos, oficiais e em uma bibliografia de apoio.

Palavras-chave: Salário-educação; financiamento da educação brasileira; políticas de financiamento da educação brasileira.

\begin{abstract}
:
This article aims to introduce the entry of education-salary in the national legal order and it further Evolution with their changes. The education-salary is a financing mechanism of the schooling process in Brazil. This is a plus to the education constitutional financing. It is an important way to make effective the right of the education with the Society collaboration and, in the case, the cooperation of the private companies, in the social function of property. This article is based on historical laws, oficial documents and on reference bibliography.
\end{abstract}

Keywords: Education-salary; the financing of brazilian education; financing policies of brazilian education. 


\section{INTRODUÇÃO}

O salário-educação se insere entre os mecanismos de financiamento da educação como relata o capítulo anterior. A questão do financiamento, desde os tempos coloniais, tem recebido um tratamento vacilante e insuficiente para as dimensões do desafio de propiciar à população brasileira uma verdadeira educação escolar.

Numa sociedade desigual e marcada por contradições, as idas e vindas das decisões acerca do financiamento da educação são expressão das tensões e pressões de diferentes camadas da população e setores da sociedade civil sobre o aparato estatal. As respostas dadas pelo governo central a essas pressões às vezes são pontuais e episódicas.

No entanto, após a proclamação da República e em especial, a partir da década de trinta, as reivindicações pela escola pública e gratuita como direito do cidadão ganham força. A publicação do Manifesto dos Pioneiros da Educação Nova é uma expressão dessa vontade de modificar o curso das coisas estabelecendo um marco fundador da escola pública.

Muitas dessas pressões desaguaram no processo constituinte de 1933/34. Desse modo, a Constituição de 1934 é a primeira a estabelecer vinculação de receitas advindas da arrecadação de tributos, fixando percentuais para cada ente federado. Observa-se, depois disso, um movimento pendular quanto à vinculação de receitas. A Constituição de 1937 não faz menção a ela e a de 1946 reintroduz a vinculação. As Constituições de 1967 e 1969, novamente não mantêm a vinculação, exceto pela determinação, na carta de sessenta e nove, da vinculação de $20 \%$ das receitas dos municípios, e ela só retorna pela Emenda Calmon, a Emenda Constitucional n ${ }^{0}$ 24, de 1/12/1983, e se mantém na Constituição de 1988.

Interessante é observar que a oscilação da vinculação de verbas para a educação nos textos constitucionais acompanha a natureza dos regimes de governo no Brasil. Constituições promulgadas em períodos de vigência de governos constitucionais acolhem a vinculação, enquanto isso não ocorre em regimes de exceção. É até esperado que seja assim, já que em regimes de exceção as pressões e anseios de amplas camadas da população não chegam ou não são acolhidas pelas esferas encarregadas de redigir o 
texto constitucional. Outrossim, esses regimes serão portadores e executores de um projeto de nação formulado pelas elites nacionais mediante as suas prioridades.

No entanto, esse processo não fica imune a contradições. A Carta de 1937 é a primeira a atribuir às empresas o dever de manter escolas para os filhos de seus empregados. Ela explicita também a ação do Estado no dever de prover, às classes menos favorecidas, o ensino profissional e prevocacional. Vale a pena reproduzir parte de seu artigo 129.

O ensino prevocacional e profissional destinado às classes menos favorecidas é, em matéria de educação, o primeiro dever do Estado. Cumpre-lhe dar execução a esse dever, fundando institutos de ensino profissionais e subsidiando os de iniciativa dos Estados, dos Municípios e dos indivíduos ou associações particulares e profissionais.

É dever das indústrias e dos sindicatos crear, na esfera de sua especialidade, escolas de aprendizes, destinadas aos filhos de seus associados. A lei regulará o cumprimento desse dever e os poderes que caberão ao Estado sobre essas escolas, bem como os auxílios, facilidades e subsídios a lhes serem concedidos pelo poder público. (BRASIL, 1937)1

Era preciso formar a classe trabalhadora a qual estaria "predestinada" a fornecer a mão de obra necessária às indústrias que se expandiam no período. Há uma massa de trabalhadores rurais chegando às cidades e, pelo menos parte dela, tem que ser escolarizada e profissionalizada para ocupar os postos de trabalho que a indústria abre no período.

Importante lembrar também que é do período do Estado Novo o arcabouço legal da nova realidade das relações de trabalho no país, consubstanciado na Consolidação das Leis do Trabalho (CLT). Lá está prefigurado o que viria a ser o Sistema S ligado ao ensino profissional, o salário do menor aprendiz e as obrigações das empresas na manutenção desses institutos. Para a formação da classe trabalhadora, o que tirou com uma mão na Carta Constitucional, o Estado providencia com outra na CLT, ainda que não seja a sua.

A Constituição de 1946, no seu artigo 168, incisos III e IV estabelece:

III- as empresas industriais, comerciais e agrícolas, em que trabalhem mais de cem pessoas, são obrigadas a manter ensino primário gratuito para os seus servidores e os filhos destes;

${ }^{1}$ Disponível em: http://www.planalto.gov.br/ccivil_03/Constituicao/Constituicao37.htm 
IV- as empresas industriais e comerciais são obrigadas a ministrar, em cooperação, aprendizagem aos seus trabalhadores menores, pela forma que a lei estabelecer, respeitados os direitos dos professores; (BRASIL, 1946) ${ }^{2}$

As Cartas de 1967 e 1969 reafirmam o dever de as empresas manterem ensino primário gratuito aos filhos dos empregados. A novidade é que elas estendem esse dever a todas as empresas, independentemente do seu porte.

A gratuidade da educação primária é declarada na Constituição de 1824, ausente na de 1891, mas já a partir da Carta de 1934 o conceito de "gratuidade ativa" é consignado como meio de garantir, além da gratuidade da educação escolar, a permanência dos alunos carentes de recursos, ao instituir assistência aos escolares. A assistência ao escolar aparece em todas as outras Constituições. Esse direito, por razões óbvias, nesses diplomas, está registrado no bojo dos mecanismos de financiamento, ainda que a carta de 1937 proponha que isso se faça pela solidariedade das famílias mais bem aquinhoadas com doações à caixa escolar.

Veja-se o artigo $157, \S \S 1^{\circ}$ e $2^{\circ}$, da Carta de 1934:

Artigo 157. A União, os Estados e o Districto Federal reservarão uma parte dos seus patrimonios territoriaes para a formação dos respectivos fundos de educação

§1.As sobras das dotações orçamentárias, accrescidas das doações, percentuais sobre o producto de venda de terras publicas, taxas especiaes e outros recursos financeiros, constituirão, na União, nos Estados e nos Municipios, esses fundos especiaes, que serão aplicados em obras educativas determinadas em lei.

$\S 2$. Parte dos mesmos fundos se applicará em auxilios a allunos necessitados, mediante fornecimento gratuito de material escolar, bolsas de estudo, assistência alimentar, dentaria e medica, e para villegiaturas. (BRASIL, 1934)3

O financiamento da educação após 1934 tem uma abrangência maior porque, além de construir, equipar, manter escolas, pagar professores e aperfeiçoar recursos humanos, há que se garantir a permanência do alunado na escola, para o que o material escolar, alimentação, transporte, assistência médica e odontológica vão concorrer.

A Constituição de 1934 acolhe a necessidade e determina a elaboração de Plano Nacional de Educação e atribui à União a competência de fixá-lo. As duas Constituições seguintes não se ocupam de nenhum tipo de plano educacional. Mas curiosamente, e

2 Disponível em: http://www.planalto.gov.br/ccivil_o3/constituicao/constituicao46.htm
3 Disponível em: http://www.planalto.gov.br/ccivil_o3/constituicao/constituicao34.htm 
não por acaso, as Constituições de 1967 e 1969 voltam a determinar a competência da União no estabelecimento de planos, o que a de 1988 também o faz.

Embora o estabelecimento de Planos Nacionais de Educação não se inscrevam, por si próprios, na órbita do financiamento da educação, ao fixá-los, parte-se do pressuposto de que recursos escassos destinados à educação precisam ser racionalmente aplicados, sob pena de se comprometer o alcance das metas pretendidas e correr o risco de desperdícios. Por sua vez, o estabelecimento de Planos Nacionais vai concorrer para que, mais facilmente e com mais eficácia, se conduzam ações de financiamento. De todo modo, Planos Nacionais ou Setoriais têm que contar explicitamente com recursos determinados e prefixados, do contrário serão letra morta, sem nenhuma factibilidade. É por isso que eles e os mecanismos de financiamento se articulam de forma inarredável e definitiva.

Então, fica evidente que as alterações pendulares nos mecanismos de financiamento, ainda que acrescido de novas fontes de recursos, criam aquilo que o professor José Carlos de Araújo Melchior chamou de paradoxo.

Verificou-se então o paradoxo, principalmente na esfera da União: à medida que novas fontes de recursos foram sendo criadas, o montante global de recursos, relativamente à receita de impostos, foi decrescendo constante $\mathrm{e}$ gradativamente; à medida que se dava por um lado, mais recursos através de fontes específicas, retirava-se, por outro lado, recursos de impostos. Como o montante global diminuiu, a conclusão só pode ser uma: os recursos canalizados através de fontes específicas foram menores que aqueles que se deixou de retirar da receita dos impostos. Deu-se por um lado e retirou-se mais por outro. (MELCHIOR, 1983, p.7)

No início da década de sessenta a lei $\mathrm{n}^{\circ}$ 4.024/61 (primeira LDB - Lei de Diretrizes e Bases da Educação Nacional) dispõe que os recursos federais destinados à educação (nove décimos) constituirão, em parcelas iguais, os Fundos Nacionais do Ensino Primário, do Ensino Médio e Ensino Superior. Determina ainda que o Conselho Federal de Educação elabore o Plano Nacional de Educação referente a cada Fundo. Assim, em 21 de setembro de 1962, o CFE entregou ao MEC o primeiro Plano Nacional de Educação que estabelecia objetivos e metas para um período de oito anos. Na sua entrega o CFE previa a necessidade de revisão, em algum tempo, dos cálculos nele constantes. Com o Plano estabelecem-se metas qualitativas e quantitativas para a educação, o que permite previsão mais precisa de recursos para que se possa realizá- 
lo. O Plano torna urgente a necessidade de aporte de novas fontes de recursos. Estão dadas as condições objetivas para o surgimento do salário- educação.

\section{A LEI No $\mathbf{N}^{\circ}$ 4.440/64, SUAS DETERMINAÇÕES, IMPACTOS E REPERCUSSÕES}

No início dos anos 6o, o poder executivo tinha, diante de si, o grande desafio de cumprir a obrigação constitucional de garantir a escolaridade obrigatória, de cumprir e fazer cumprir as determinações da Lei n. ${ }^{0}$ 4.024/61, que claramente dispõe sobre a destinação dos recursos previstos na Constituição para a educação e de perseguir a realização das metas estabelecidas no Plano Nacional de Educação de 1962 - matrícula até a quarta série de 100\% da população escolar de 7 a 11 anos e matrícula, na quinta e sexta séries, de 70\% da população de 12 a 14 anos. Na prática, além de fixar o atendimento de $100 \%$ da população escolarizável, o Plano estende a escolarização obrigatória até aos 14 anos, o que aumenta significativamente o universo a ser atendido. A meta de erradicar o analfabetismo no Brasil exigiria mais disponibilidade financeira do que a existente. Entendendo a importância desse momento para a educação, o Professor Carlos Pasquale, herdeiro de uma longa tradição de pensamento ligado à educação e à escola pública, formula em conformidade com essa herança, proposta de novo mecanismo de financiamento da educação que, acreditava-se então, poderia aportar os recursos necessários às demandas da expansão do ensino e o submete à apreciação do MEC. Passo seguinte, o Poder Executivo encaminha ao Congresso projeto de lei, que sancionada em 27/10/1964, se torna a Lei n. 4.440/64, regulamentada pelo Decreto $\mathrm{n}^{\circ} 55.551$ de 12/1/65, alterado pelo Decreto $\mathrm{n}^{0} 58.093$ de 28/3/66, que institui o salário-educação. Trata-se de uma contribuição devida pelas empresas destinada a suplementar os recursos públicos reservados para o ensino primário. Diz a lei (BRASIL, 1964)4:

LEI No 4.440, DE 27 DE OUTUBRO DE 1964.

Institui o Salário-Educação e dá outras providências.

O PRESIDENTE DA REPÚBLICA, faço saber que o Congresso Nacional decreta e eu sanciono a seguinte Lei:

4 Disponível em: https://bit.ly/lei4440 
Art. $1^{0}$ é instituído o salário-educação devido pelas emprêsas vinculadas à Previdência Social, representado pela importância correspondente ao custo do ensino primário dos filhos dos seus empregados em idade de escolarização obrigatória e destinado a suplementar as despesas públicas com a educação elementar.

Art. $2^{\circ} \mathrm{O}$ custo atuarial do ensino primário, para os efeitos do artigo $1^{\circ}$ desta leis, será calculado sob a forma de quota percentual, com base no saláriomínimo local, arredondando êste para múltiplo de mil seguinte.

Art. $3^{\circ} \mathrm{O}$ salário-educação será estipulado pelo sistema de compensação do custo atuarial, cabendo a tôdas as emprêsas recolher, para êsse fim, ao Instituto ou Instituições de Aposentadoria e Pensões a que estiverem vinculados. Em relação a cada empregado, qualquer que seja o seu estado civil e o número de seus filhos, a contribuição que for fixada em correspondência com o valor da quota percentual referida no art. $2^{\circ}$.

$\S 1^{0}$ A contribuição de que trata êste artigo corresponderá a percentagem incidente sôbre o valor do salário-mínimo multiplicado pelo número total de empregados da empresa, observados os mesmos prazos de reconhecimento, sanções administrativas e penais e demais dados estabelecidos com relação ás contribuições destinadas ao custeio da Previdência Social.

$\S 2^{\circ} \mathrm{O}$ salário-educação não tem caráter remuneratório na relação de emprêgo e não se vincula, para nenhum efeito, ao salário ou à remuneração recebida pelos empregados das emprêsas compreendidas por esta Lei.

$\S 3^{\circ}$ É vedado aos Institutos de Aposentadoria e Pensões receber das emprêsas quaisquer contribuição relativas à Previdência Social, que, ressalvado o disposto nos arts. $5^{\circ}$ e $6^{\circ}$, não incluam as parcelas que forem devidas nos termos desta Lei.

Art. $4^{\mathrm{o}}$ As contribuições recolhidas nos Estados, no Distrito Federal, e nos Territórios, deduzida a parcela de meio porcento relativa às despesas de arrecadação, serão depositadas dentro de sessenta (60) dias, sob pena de responsabilidade civil e penal, pelos Institutos de Aposentadoria e Pensões no Banco do Brasil S. A. em duas contas distintas:

a) 50\% a crédito do Fundo Estadual de Ensino Primário ou, na inexistência dêste, em conta vinculada ao "desenvolvimento do ensino primário", a crédito do respectivo govêrno para aplicação de conformidade com o $\S 1^{\circ}$ dêste artigo; b) $50 \%$ em conta vinculada ao Fundo Nacional do Ensino Primário como refôrço de seus recursos para aplicação em todo o território nacional, na conformidade e segundo os mesmos critérios de distribuição estabelecidos pelo Conselho Federal de Educação $\left(\S 2^{\circ}\right.$ do art. 92 da Lei $n^{0} 4.024$, de 20 de dezembro de 1961), o qual levará em conta sôbretudo a razão direta dos índices de analfabetismo.

$\S 1^{\circ}$ Os recursos de que trata a letra a dêste artigo serão aplicados nos Estados, e no Distrito Federal, de acôrdo com planos estabelecidos pelos respectivos Conselhos Estaduais de Educação, e nos Territórios, de conformidade com os critérios que forem fixados pelo Conselho Federal de Educação.

$\S 2^{\circ}$ Durante os três primeiros anos de vigência desta Lei, $40 \%, 50 \%$ e 60\%, respectivamente, dos recursos do salário-educação serão obrigatoriamente aplicados em despesas de custeio e o restante em construções e equipamentos de salas de aula. Nos anos seguintes, a percentagem atribuída a construção e equipamentos será fixada pelo Conselho Federal de Educação.

Art. $5^{\circ}$ Ficarão isentos do recolhimento da contribuição de que trata o art. $3^{0}$ : a) as emprêsas que, com mais de cem (100) empregados, mantiverem serviço próprio de ensino primário (art. 168, III, da Constituição Federal) que instituírem, inclusive mediante convênio de bolsas de estudo no mesmo grau de ensino, um e outro, em termos julgados satisfatórios por ato da administração estadual de ensino, aprovado pelo Conselho Estadual de Educação, na forma da regulamentação desta lei: 
b) as instituições de ensino e educação, de qualquer tipo ou grau, bem assim os hospitais e demais organizações de assistências que não tenham fins lucrativos.

Parágrafo único. A isenção de que trata a letra a dêste artigo, concedida pelo prazo de um ano. Será renovada mediante comprovação da regularidade das providências realizadas, dos resultados obtidos e das despesas efetivamente feitas em importância não inferior às contribuições que seriam dividas na forma do art. $3^{\circ}$.

Art. $6^{\circ}$ (VETADO)

Parágrafo único. (VETADO)

Art. $7^{\circ}$ Com o recolhimento do salário-educação, instituído por esta Lei, ou por ato de autoridade competente da administração estadual do ensino, baixado nos têrmos do art. $5^{\circ}$, considerar-se-á atendido pela emprêsa em relação aos filhos de seus empregados, o estatuído no art. 168, no III, da Constituição Federal.

Parágrafo único. O disposto no art. 168 nº III, da Constituição Federal, será comprido pelas emprêsas em relação aos seus próprios servidores, na forma da Legislação Estadual.

Art. $8^{\circ}$ Ficam assim fixados, pelo período, de três anos, as idades e valores efetivos a esta Lei:

I - 7 a 11 anos de idade a escolarização obrigatória, a que se refere o art. $1^{\circ}$;

II - Sete por cento do salário-mínimo para a quota percentual referida no art. $2^{\mathrm{o}}$;

III - Dois por cento para a contribuição pelas emprêsas nos têrmos do art. $3^{\circ}$, $\S 1^{\circ}$.

$\S 1^{\mathrm{o}}$ Se, findo o período previsto neste artigo, não forem, por decreto do Govêrno Federal, revistas as idades e valores nêle fixados, êstes continuarão em vigor até o nôvo decreto.

$\S 2^{\mathrm{O}}$ A qualquer alteração das idades ou das porcentagens referidas nos incisos I, II e III dêste artigo, deverá corresponder proporcionalmente as das outras, a fim de que seja assegurado o equilíbrio do sistema de custeio.

Art. $9^{\circ} \mathrm{O}$ Ministério da Educação e Cultura fiscalizará a aplicação de todos os recursos provenientes do salário-educação, de conformidade com as instruções que forem baixadas para êsse fim e nos têrmos dos convênios gerais que deverão ser firmados com os governos estaduais.

Art. 10. Esta Lei entrará em vigor a partir do mês que se seguir ao decurso de trinta dias, contados da data de sua publicação.

Parágrafo único. Dentro do prazo estabelecido neste artigo o Poder Executivo expedirá o regulamento desta lei.

Art. 11. Revogam-se as disposições em contrário.

Brasília, em 27 de outubro de $1964 ; 143^{\circ}$ da Independência e $76^{\circ}$ da República.

H. Castelo Branco

Flavio Suplicy Lacerda

Arnaldo Sussekind

Ela amplifica a responsabilidade solidária das empresas para com a educação escolar primária na medida em que estende a todas as empresas vinculadas à Previdência Social a compulsoriedade dessa contribuição.

Importante anotar que a lei, de fato, introduz uma nova realidade na educação brasileira: a determinação do custo do ensino primário por aluno. O então Instituto 
Nacional de Estudos Pedagógicos (INEP) foi acionado para realizar estudos com esse fim. A esse respeito transcreve-se a descrição, feita pelo professor Carlos Pasquale, desses cálculos.

Admitindo-se que:

a) se atribua ao professor das classes de ensino primário a remuneração equivalente a 1,5 salário-mínimo (SM);

b) as despesas com a remuneração do professor correspondam a 70\% do custo total da manutenção desse ensino, sendo os 30\% restantes representados pelas despesas de livros e material escolar (13\%), prédio e equipamento (10\%), direção e supervisão do ensino ( $7 \%$ );

c) a matrícula média por classe seja de 30 alunos, o custo mensal per- capita do ensino primário, em cada região do país, será dado pela fórmula:

$$
\frac{1,5 S M}{70} \times \frac{100}{30}=0,07 S M
$$

O custo do ensino primário assim determinado (7\% do salário mínimo) será devido pelas empresas em relação a cada um dos filhos de empregados em idade de escolarização obrigatória.

De acordo com as estimativas atuariais realizadas pelo Ministério do Trabalho e Previdência Social, e com índices etários aplicados ao Censo de 1960, correspondem a cada 100 filiados aos diversos Institutos de Previdência Social 30 menores de 7 a 11 anos de idade. A contribuição relativa a cada empregado ativo deverá ser, então, 30\% do custo do ensino primário de uma criança, isto é:

$$
\frac{30}{100} \times \frac{(7 S M)}{100}=0,02 S M
$$

A contribuição assim fixada ( $2 \%$ do salário mínimo) é que constitui o chamado "salário- educação" e será arrecadada pelos Institutos de Previdência a que as empresas estiverem vinculadas. (PASQUALE, 1965, p.21)

O salário-educação, desde o seu estabelecimento, teve sua aplicação determinada no diploma legal, como se vê acima, inclusive com impacto federativo. A divisão entre União e Estados tem um viés compensatório das diferenças regionais, de vez que a maior arrecadação ocorre nos estados mais desenvolvidos, industrializados e populosos. À União caberia, em conformidade com a Lei de Diretrizes e Bases, aplicar os 50\% recolhidos a ela na razão direta dos índices de analfabetismo. Ora, são os estados menos desenvolvidos os que detêm os índices mais altos de analfabetismo. Em 1960, enquanto na região sul (engloba as regiões sul e sudeste) 70,5\% da população infantil estava na escola, esses percentuais desciam a 40,5\% no nordeste e $36,1 \%$ na região norte-oeste (Pasquale, 1965). Acresce que o fenômeno da urbanização, crescendo na década de sessenta, é maior no sul-sudeste. $\mathrm{O}$ atendimento a crianças dispersas na zona rural é muito mais precário. 
Chama atenção também, na Lei n ${ }^{\circ}$ 4.440/64, que, ao determinar a aplicação de recursos, o legislador, além da sua divisão, indica como e em que devem ser aplicados. A aplicação de recursos deve seguir os planos estaduais de educação, obedecidos os critérios estabelecidos pelo CFE. Desde a Lei de Diretrizes e Bases da Educação, tenta o Poder Público trabalhar em educação sistemática e planejadamente, perseguindo metas quantitativas e qualitativas. Quanto aos percentuais, ela estabelece, nos três primeiros anos de vigência, a obrigatoriedade de se aplicar respectivamente $60 \%, 50 \%$, 40\% na construção de salas de aula. Essa providência mostra a preocupação do legislador na expansão do ensino. Para atender às metas do Plano Nacional de Educação, de acréscimo de matrículas no período de 1964 a 1970, seria necessário construir mais de 140.000 salas de aula (matrícula média de 35 alunos por classe e dois turnos por dia) (PASQUALE, 1966).

A compulsoriedade do recolhimento, o legislador a consegue, vedando à Previdência Social recolher contribuições sociais sem as parcelas devidas do salárioeducação. Garantiram-se, assim, a regularidade do recebimento e uma estrutura de arrecadação e fiscalização já existente e presente em todo território nacional. Tanto é assim que estudiosos do salário-educação vão, nos anos seguintes, apontar a facilidade de arrecadação e a dificuldade de sonegação como fatores de sucesso da contribuição.

Outro aspecto importante a assinalar na lei é que ela permite outras formas alternativas de cumprimento da obrigação por empresas de mais de cem empregados, qual seja a manutenção de serviço próprio de ensino primário aos filhos de empregados em idade de escolarização ou a instituição de bolsas de estudo, mediante convênio, em escolas particulares. Esse instituto vai se revelar, ao longo desses 42 anos, uma fonte de controvérsias e disputas que opuseram, no passado, publicistas e privatistas. A disputa de recursos públicos pelas esferas privadas não se resolve e, na instituição do salário-educação, ela vai assumir contornos próprios.

A lei contempla, ainda, a isenção do recolhimento da contribuição às empresas de ensino, de qualquer nível ou grau e hospitais e organizações de assistência social sem fins lucrativos, além, é claro, das empresas que mantiverem ensino próprio ou sistemas de bolsas. Esse dispositivo, ao longo do tempo, altera-se significativamente, fruto de disputas e tensões de interesses conflitantes da organização social. 
Finalmente, um outro dispositivo da lei, que fixa a idade das crianças a serem atendidas e os valores atribuídos à contribuição (incisos I, II e III do artigo 8), os vincula entre si, de tal forma que qualquer alteração em um deles implicará proporcionalmente na alteração dos demais. Pretende-se, com o dispositivo, garantir o equilíbrio do sistema de custeio e abertura a revisões periódicas a serem fixadas por decreto.

Da mesma forma que nas outras receitas destinadas à educação escolar, instituídas em outros diplomas legais, as contradições da sociedade brasileira e o jogo de pressões por parte de setores mais organizados e ou influentes manifestaram-se, implicando em fluxos e refluxos nas formulações desse corpo legal; a instituição do salário-educação irá trazer, para sua órbita, velhas e contínuas disputas. Ao analisar as alterações e complementações por que passará a lei sancionada em 27 de outubro de 1964, pode-se identificar reinvindicações antagônicas entre estados mais e menos desenvolvidos, luta pela repartição dos recursos entre partidários da escola pública e dos interesses privados, queda de braço entre poder público e empresas contribuintes, movimentos opostos de centralização e descentralização das políticas de educação, tensão entre as esferas federal, estadual e municipal em torno dos recursos do salárioeducação e competências na sua aplicação. Certamente esse embate, em grande parte, explica a abundância de leis, decretos-lei, decretos, portarias, instruções que, direta ou indiretamente, vem alterando diversos aspectos do salário- educação.

Antes que se passe a percorrer a trajetória das principais alterações no ordenamento jurídico, é necessário registrar as expectativas com a instituição do salário-educação e algumas repercussões da sua criação.

Quanto à expectativa do volume de recursos a ser gerado, o professor Carlos Pasquale assim se manifesta:

O salário-educação introduz um elemento novo, altamente significativo, na economia do ensino primário, destinado a proporcionar, de pronto, recursos para o financiamento da educação de 1,5 milhão de alunos, elevando de $25 \%$ o número de matrículas correspondentes a crianças de 7 a 11 anos. (PASQUALE, 1966, p.195) ${ }^{5}$

E quanto ao seu potencial de crescimento, o mesmo autor assim se expressa:

5 Para uma biografia de Pasquale, cf. Fávero e Britto (1999). 
O sistema adotado apresenta, ainda, a vantagem de ajustar automaticamente a arrecadação a todo crescimento demográfico e a toda elevação de custo de vida.

No decorrer dos próximos anos, a arrecadação e, conseqüentemente, o vulto dos benefícios, deverão aumentar também em decorrência de outros fatores: a progressiva extensão da previdência social a categorias de profissionais atualmente não abrangidas pelos institutos incumbidos da arrecadação e o próprio aperfeiçoamento da organização desses órgãos. (PASQUALE, 1966, p.195)

Desde a Conferência De Punta del Este, da qual o Brasil participou e na qual o Professor Carlos Pasquale teve atuação destacada, os países da América Latina firmam compromissos acerca do crescimento econômico e, no Plano Decenal de Educação, fixam metas a serem alcançadas até 1970. Para tal o plano orienta que:

\footnotetext{
Para completar os recursos internos disponíveis para a execução de planos integrais de educação, o Fundo Interamericano de Desenvolvimento Social, o Banco Interamericano de Desenvolvimento e outras fontes de crédito proporcionem empréstimos para bem concebidos projetos nacionais e regionais de desenvolvimento educativo, particularmente para edifícios e equipamento escolares. (PASQUALE, 1966, p.218)
}

Também na Conferência de Santiago do Chile, em 1962, novamente os países são instados a tomar as providências necessárias para destinar à educação mais recursos para cumprir as metas do Plano Decenal. (PASQUALE, 1966)

Essa preocupação, formulada por países participantes de conferências internacionais e transformada em compromissos de promover ações para o desenvolvimento da educação e combate ao analfabetismo, já durava uma década. Por isso, quanto às repercussões, principalmente as internacionais, embora contribuições patronais, voluntárias ou compulsórias não fossem novidade, pois em 1955, em Genebra, na XVIII Conferência Internacional de Instrução Primária, houve relatos de sua adoção em 23 países, a criação do salário-educação pelo Brasil não passa despercebida. Segundo Fábio Veloso, ela foi divulgada no "Prontuário de la Legislación Educativa de América” (Serviço de Documentação do Departamento de Assuntos Educativos da União Pan-Americana $\left.n^{0} 3 / 15\right)$, comentada no artigo "L’Enseignement au Brésil” na revista Pedagogie, Education,et Culture ( Centro d'Etudes Pedagogiques - Paris, $\mathrm{n}^{0} 2$ 1966). Foi, ainda objeto de debates no Congresso Mundial de Ministros da Educação sobre Eliminação de Analfabetismo (Teerã, setembro de 1965) e na IV 
Reunião do Conselho Interamericano Cultural da Organização dos Estados Americanos (Washington, janeiro de 1966).

\section{SALÁRIO-EDUCAÇÃo - EVOLUÇÃO DE SUA REGULAMENTAÇÃo}

Mal tinha sido criado, o salário-educação sofre sua primeira e significativa alteração. A lei no 4.863 de 29/11/65, que altera as alíquotas da quota da Previdência Social, regulamentada pelo Decreto ${ }^{0} 57.902$ de 02/3/66, altera a base de cálculo do salário-educação. O percentual a ser recolhido passa a ser de 1,4\% do salário de contribuição definido na legislação social, ao invés de $2 \%$ sobre o salário mínimo. Essa alteração vai permitir aumento significativo do volume arrecadado. E de fato assim se comporta. Desde sua criação até meados da década de setenta há um aumento de arrecadação em termos reais. ${ }^{6}$

No entanto, as constituições de 1967 e de 1969 eliminaram a vinculação de receitas para educação, como foi dito. Do ponto de vista da regulamentação do salárioeducação, a Carta de 1969 consagra, no seu artigo 178, a contribuição do salárioeducação como mecanismo de financiamento. Novamente a contradição de dar com uma mão e retirar com a outra se manifesta na própria Constituição.

Nesse biênio um passo importante no encaminhamento dos recursos do salárioeducação é dado com a criação, pela Lei $n^{0}$ 5.537, de 21/11/68, do INDEP, depois renomeado FNDE pelo Decreto-Lei $\mathrm{n}^{\circ}$ 872, de 15/09/69, cuja finalidade fica determinada no seu artigo $2^{\circ}$.

O FNDE tem por finalidade captar recursos financeiros e canalizá-los para o financiamento de projetos de ensino e pesquisa, incluindo alimentação escolar e bolsa de estudo, observadas as diretrizes do planejamento nacional da educação. (BRASIL, 1969)7

Embora haja outras fontes de recursos, ainda que não mais vinculadas, pelo menos até 1983, a mais importante torna-se o salário-educação. Nessa primeira década de existência da contribuição das empresas, muitos outros dispositivos legais foram

${ }^{6}$ Não se pode esquecer concomitantemente, a despeito das avaliações já feitas, o aparecimento da Lei n. 5.379/67, que cria o MOBRAL.

7 Disponível em http://www.planalto.gov.br/ccivil_03/Decreto-Lei/1965-1988/Delo872.htm 
exarados com a finalidade de orientar e normatizar o processo "de arrecadação e aplicação dos recursos do salário-educação.” (MEC/FNDE). As mais importantes revelam as dificuldades de operacionalização de sua arrecadação e aplicação, tais como:

a) Dificuldades na transferência dos recursos arrecadados pela previdência social: Decreto $\mathrm{n}^{0}$ 65.317, de 10/10/69, fixa dispositivos para transferência mensal ao Tesouro Nacional pelo Banco do Brasil e a transferência automática ao FNDE. Decreto $n^{0}$ 68.592, de 6/5/71, que retira a intermediação do Tesouro e restabelece a transferência direta do Banco do Brasil ao FNDE.

b) Disciplinamento da assistência financeira da União aos Estados e Municípios: Decreto $\mathrm{n}^{\mathrm{0}}$ 63.340, de 1/10/68, determina aos Estados e Municípios contrapartida de igual valor daquela disponibilizada pela União.

c) Controle de isenções do recolhimento do salário-educação: Resolução FNDE $n^{0} 34$, de 11/11/72, que normatiza a expedição de certificados de isenção; Resolução no 3 , de 13/2/73, delega às Secretarias Estaduais de Educação a emissão dos certificados; Resolução $\mathrm{n}^{0} 7$, de 2/3/73, normatiza a sistemática de apuração de alunos beneficiados com bolsas ou serviços próprios de ensino pelas empresas.

Principalmente as dificuldades relativas ao controle de isenções e de alunos com bolsas e serviço próprio vão se arrastar e persistir durante as décadas de setenta e oitenta. É em torno dessa questão que serão travadas as disputas pelos recursos públicos.

Sob a gestão de Jarbas Passarinho no Ministério da Educação, é sancionada a Lei $n^{0} 5.692$, de 11/8/71. Essa lei, na verdade uma alteração da Lei ${ }^{0}$ 4.024/61, regula a escolaridade obrigatória de 6 anos para 8 anos (já estabelecida no texto constitucional de 1967) que passa a se chamar ensino de primeiro grau, exigindo um acréscimo considerável de recursos para o seu cumprimento. No seu capítulo VI, acerca do financiamento, reafirma, por meio de seu artigo 41, o dever do Estado, em todas as suas esferas, para com a educação e o estende às empresas e famílias de forma solidária. 
No seu artigo 43 (BRASIL, 1971) , reafirma também que os "recursos públicos destinados à educação serão aplicados preferencialmente na manutenção do ensino oficial.” Em torno desse advérbio, preferencialmente, vão se intensificar as pressões da iniciativa privada que é contemplada, no artigo 45, com amparo financeiro do Poder Público.

Em 1975, tendo como Ministro da Educação o senador Ney Braga, ocorre a segunda grande regulamentação do salário-educação, propondo profundas alterações. O Decreto-lei $n^{0}$ 1.422, de 23/10/75, regulamentado pelo Decreto $n^{0} 76.923$, de 23/12/75, e que revoga a lei $\mathrm{n}^{\mathrm{o}} 4.440 / 64$, estabelece, no seu artigo $1^{\mathrm{o}}$, que o salárioeducação é obrigação devida pelas empresas comerciais, industriais e agrícolas. É a primeira vez que as empresas agrícolas passam a ser passíveis de recolhimento da contribuição, mas logo no seu parágrafo $2^{0}$ suspende a cobrança para aquelas vinculadas ao FUNRURAL (na prática todas as empresas agrícolas).

Como a discussão acerca do que seriam as empresas sujeitas ao recolhimento persistiam, ao longo da década anterior, o parágrafo primeiro toma emprestado da CLT a definição ali contida: “Artigo $2^{\circ}$ - Considera-se empregador a empresa, individual ou coletiva, que, assumindo os riscos da atividade econômica, admite, assalaria e dirige a prestação de serviços.” (BRASIL, 1943) 9

Outro objetivo desse Decreto foi o de revogar a competência supletiva dos Estados para legislarem sobre o salário-educação, permitida pela Lei $n^{0}$ 4.440/64. Segundo aquele diploma, os Estados poderiam, por meio de legislação estadual instituir o que ficou conhecido como "salário-educação 2", ou, ainda "parcela estadual do salário-educação.” No entanto, nem todos os Estados exerceram esse direito, de tal forma que havia aqueles que o recolhiam e a maioria que não o fazia. A "alíquota estadual" era de $0,6 \%$ sobre a mesma base de cálculo do salário-educação propriamente dito.

Além da definição acerca das empresas obrigadas à contribuição e da revogação do "salário-educação 2", esse diploma legal apresenta as seguintes alterações relevantes:

8 Disponível em: https://bit.ly/lei5692

9 Disponível em: http://www.planalto.gov.br/ccivil_o3/decreto-lei/del5452.htm 
a) altera a alíquota de 1,4\% para 2,5\% da folha de salário de contribuição em decorrência da atualização dos cálculos do custo do ensino;

b) altera os critérios de distribuição da receita, de duas partes iguais para 2/3 da arrecadação líquida aos estados - quota estadual e 1/3 para o FNDE quota federal;

c) permite às empresas que mantiverem sistema próprio de ensino de $1^{0}$ grau atender, além de empregados e seus filhos, quaisquer adultos e crianças;

d) introduz o financiamento do ensino supletivo de $1^{\mathrm{o}}$ grau pelo salárioeducação;

e) permite às empresas indenizar a autopreparação de seus empregados via exame supletivo e de seus filhos menores cursando $1^{\circ}$ grau em escolas pagas;

f) permite às empresas adotar sistema misto de cumprimento de suas obrigações;

g) estabelece a sistemática de estimativa de receita pelo INSS para transferência dos recursos aos Estados e FNDE, com posterior encontro de contas;

h) altera para 1\% a remuneração do INSS pela arrecadação e fiscalização do salário-educação.

Esses dois instrumentos legais provocam, como consequência de sua adoção, um aumento considerável da arrecadação em termos nominais, mas que se fazia necessário face à extensão da obrigatoriedade e gratuidade do ensino supletivo de primeiro grau no mesmo mecanismo de financiamento.

Outra consequência importante advém da nova divisão de recursos entre União e Estados. Ganham os Estados mais desenvolvidos economicamente, cuja arrecadação é proporcionalmente muito maior que os outros e a União tem diminuída sua capacidade federativa de redistribuir recursos, por meio da quota federal, com o fim de diminuir as disparidades regionais. Sobre esse efeito, assim se expressa a professora Ecilda Ramos de Souza, Secretária Executiva do FNDE: arrecadação e a despesa, notaremos, por exemplo, que na Região Norte a arrecadação representa $2 \%$ do País; no entanto, na hora de devolver, a nível de despesa, esta Região recebeu 5 vezes mais o que arrecadou; o Nordeste 
pouco mais de 4; o Sudeste perde na redistribuição; o Centro-Oeste ganha 4 vezes; o Sul também perde. (SOUZA, 1983, p.3)

Essas considerações foram feitas quando a repartição de recursos destinava aos Estados 2/3 do total arrecadado. Pode-se imaginar qual seria o efeito compensatório, se a repartição ainda se fizesse em partes iguais entre União e Estados. Talvez as diferenças pudessem ter sido diminuídas em favor dos Estados do Norte e Nordeste. Embora a citação acima aponte para as possibilidades compensatórias remanescentes, e fique evidente o quanto esse mecanismo funciona para tentar equalizar situações radicalmente diferentes e injustas, a alteração da repartição acaba afetando a potencialidade das políticas compensatórias.

Mais um efeito resultará do cumprimento desses dois dispositivos legais: há um alargamento das isenções, permitindo a mais empresas o não recolhimento da contribuição. Na década de oitenta, quando o país entra em recessão, esses recursos farão falta e os dispositivos serão objeto de estudos e discussão no MEC/FNDE.

No entanto, nenhum efeito gerado pelos dois instrumentos legais adotados em 1975 se compara à abertura que se dá às empresas com as alternativas de cumprimento da obrigação por meio da adoção de uma ou mais alternativas de atendimento e da permissão de atendimento a outros adultos e crianças que não os empregados e seus filhos.

Depois da entrada em vigor desses decretos, muitos outros instrumentos normativos são exarados, quase todos para controlar as formas alternativas de cumprimento da contribuição e coibir abusos.

Em 22 de março de 1982, sendo Ministro da Educação o general Rubem Ludwig, é sancionado o Decreto no 87.043, dando nova regulamentação ao Decreto-lei $\mathrm{n}^{\mathrm{o}} 1.422$, de $23 / 10 / 75$. Por esse decreto foram introduzidas as seguintes alterações principais:

a) volta a definir empresas sujeitas à contribuição, estendendo o conceito a empresas públicas, sociedades de economia mista, vinculadas à Previdência Social.

b) Cria alíquota, a título de salário-educação, de o,8\% do valor comercial dos produtos rurais, embora suspenda a sua cobrança; 
c) O FNDE passa a fixar o custo do ensino efetivo de $1^{0}$ grau e, em consequência, o valor da bolsa (preço da vaga em escolas pagas);

d) Permite o atendimento de adultos e crianças não vinculados às empresas também pelo sistema de bolsas, além de poder atendê-las em escola própria;

e) Atribui ao FNDE a intermediação do sistema de bolsas, adquirindo vagas em escolas particulares.

Esse decreto consolida o que passou a ser conhecido como Sistema de Manutenção de Ensino - SME, que acolhe, no ensino privado, os empregados, seus filhos e o que ficou conhecido como alunos da comunidade, que são aqueles alunos não vinculados à empresa contribuinte e atendidos pelo sistema de bolsas. Ele permitiu um carreamento de recursos públicos para o ensino privado como nunca antes havia ocorrido. A esse respeito novamente a citada Professora Ecilda assim se manifesta:

\begin{abstract}
A empresa pode optar, nós temos cerca de 1 milhão de empresas, hoje filiadas à Previdência Social; deste milhão de empresas, algumas poucas, ao longo dos anos, optaram por oferecer ensino, elas próprias. Estas empresas eram 2.076; hoje, são cerca de 30.0oo. Apesar de poucas, são as maiores empresas do País. Como há uma concentração muito grande de renda no sistema empresarial, temos, no sistema de manutenção de ensino, 34\% das 500 maiores empresas privadas e $74 \%$ das 50 maiores empresas estatais por vendas; exemplos: a Rede Ferroviária Nacional, a Petrobrás, a Vale do Rio Doce etc.

Com essa situação, no ano passado, foi a seguinte a distribuição dos recursos do Salário-Educação; tivemos 105 bi arrecadados para distribuição entre Estados e União e a manutenção do ensino chegou a 62 bi para bolsas; como esse recurso fica todo no setor privado, achamos que precisa haver, imediatamente, uma correção no sentido de que esses recursos sejam recanalizados, porque eles se subtraem do setor oficial e este é responsável por 90\% das matrículas de $1^{\circ}$ grau no País. (SOUZA, 1983, p.3)
\end{abstract}

No início de 1983, diante da situação apontada pela Secretária Executiva do FNDE, a Ministra da Educação, Esther de Figueiredo Ferraz, por meio da Portaria no 81 de 23/2/83, instala grupo de trabalho, junto ao FNDE, com finalidade de estudar a sistemática de funcionamento do salário-educação e propor medidas para seu aperfeiçoamento. O relatório do grupo apontou os seguintes problemas:

a) O crescimento do Sistema de Manutenção de Ensino, dado o volume e número de empresas a ele vinculado, prejudica o fluxo de recursos para o sistema oficial de ensino;

b) A modalidade de aquisição de vagas é de difícil controle e desvirtuamentos e abusos surgiram comprometendo as finalidades do salário-educação; 
c) Houve concentração dos recursos destinados ao SME nos grandes aglomerados urbanos, em prejuízo das periferias pobres das metrópoles e do interior, particularmente da zona rural do país, diminuindo a eficácia das políticas compensatórias;

d) Houve concentração dessas tendências nos Estados mais influentes com efeito irradiador.

Considerando que 80\% dos beneficiados do sistema de aquisição de vagas são alunos sem vinculação com as empresas que "financiam” seu ensino, e grande parte deles “não carentes”, o grupo de trabalho propõe alteração na legislação.

Em razão dos argumentos levantados pelo MEC e das repercussões dos desvios apontados pela imprensa e objeto de investigação do Tribunal de Contas da União, o Poder Executivo baixa o Decreto $n^{\circ} 88.374$, de 7/6/83, que altera os artigos $5^{\circ}, 7^{\circ}, 9^{\circ}$ e $10^{\circ}$ do Decreto $n^{\circ} 87.043 / 82$ e dá outras providências.

As principais alterações:

a) quanto à administração dos recursos- as cotas federal e estadual devem ser mantidas em depósito no Banco do Brasil, de onde só podem ser retirados para aplicação conforme determina a lei;

b) quanto à concessão de auxílios - reintroduz o critério de carência para a concessão de auxílios, na forma disposta nos artigos 43 e 54 da lei $n^{0}$ $5.692 / 71$, no atendimento à população de 7 aos 14 anos em déficit de escolarização.

c) quanto à extensão do programa de bolsas pelas empresas optantes pelo SME - restringe aos empregados e seus filhos os beneficiários dessa modalidade de atendimento;

d) quanto à aplicação dos recursos - da quota federal, destina, no mínimo 25\% para a transferência direta aos municípios para apoiar programas municipais ou intermunicipais de desenvolvimento do ensino de $1^{\mathrm{o}}$ grau.

Essa última alteração vem atender a reinvindicação dos municípios, formulada ao CFE na forma de consulta, objeto do parecer de $n^{0} 2.407 / 76$, favorável a ela, e relatado pela então conselheira Esther de Figueiredo Ferraz, e à constatação, pelo IBGE, de que em 1979, 33\% das matrículas de $1^{\circ}$ grau eram de responsabilidade do Município e, no Nordeste, chegavam a ocupar posição majoritária. 
Com duas décadas de atraso dá-se um passo para o cumprimento do disposto no artigo 58, § único da Lei $\mathrm{n}^{0} 5.692 / 71$, qual seja a "passagem progressiva para a responsabilidade municipal de encargos e serviços de educação, especialmente de $1^{0}$ grau, que pela sua natureza possam ser realizados mais satisfatoriamente pelas administrações locais,"

A década de oitenta trará três medidas legais de grande impacto na educação. A primeira, a Emenda Constitucional $\mathrm{n}^{\mathrm{o}} 24$, de $1^{\circ}$ de dezembro de 1983, chamada Emenda Calmon, de autoria do senador João Calmon, faz retornar ao texto constitucional a vinculação de receitas para a educação. Seu texto diz:

\begin{abstract}
Artigo único - O artigo 176, da Constituição Federal, passa a vigorar com o acréscimo do seguinte parágrafo:

$\S 4^{\circ}$ - Anualmente, a União aplicará nunca menos de treze por cento e os Estados, o Distrito Federal e os Municípios vinte e cinco por cento, no mínimo, da receita resultante de impostos na manutenção e desenvolvimento do ensino. (BRASIL, 1983b) ${ }^{10}$
\end{abstract}

A segunda é a Lei n ${ }^{0} 7 \cdot 348$, de 24/7/85, que regulamenta a alteração introduzida pela Emenda Calmon na Constituição vigente. No seu artigo $2^{\circ}$, dispõe:

Os recursos destinados à manutenção e ao desenvolvimento do ensino, resultantes dos percentuais estabelecidos no $\S 4^{\circ}$ do art. 176 da Constituição Federal, visam assegurar preferencialmente o cumprimento do preceito da escolarização obrigatória e garantir:

a) as mais amplas oportunidades educacionais, proporcionando-se a todos o acesso à escola e a permanência nos estudos;

b) a melhoria crescente da qualidade do ensino;

c) o desenvolvimento da pesquisa educacional;

d) o aperfeiçoamento dos recursos humanos necessários à manutenção e ao desenvolvimento do ensino;

e) o progresso quantitativo e qualitativo dos serviços de educação;

f) o estímulo à educação e a justa distribuição de seus benefícios; (BRASIL, $1985)^{11}$

Ela estabelece muito claramente o que constitui a receita de impostos arrecadados por cada ente federado e, principalmente, o que não constitui.

Art. $5^{\circ}$ - Para efeito do cumprimento do preceito estabelecido no $\S 4^{\circ}$ do artigo 176 da Constituição Federal, não serão computadas as aplicações de receitas oriundas de contribuições ou tributos que não sejam propriamente ditos,

${ }^{10}$ Disponível em: https://bit.ly/em24-1983

${ }^{11}$ Disponível em https://bit.ly/l7348_1985 
especialmente as referentes ao Fundo de Investimento Social - FINSOCIAL e ao salário-educação. (BRASIL, 1985)

O legislador, com essa redação, assegura o caráter suplementar do salárioeducação e cerceia a adoção de expedientes que viessem "maquiar" os recursos vinculados.

A terceira e a mais importante é a nova Constituição Federal, promulgada em 5 de outubro de 1988. Os percentuais vinculados são mantidos para os Estados e Municípios, mas a União passa a ter de aplicar $18 \%$ da receita de impostos, por ela arrecadados. O seu texto sobre salário-educação diz o seguinte no seu artigo 212, $\S 5^{\circ}$ :

O ensino fundamental público terá como fonte adicional de financiamento a contribuição do salário-educação recolhida, na forma da lei, pelas empresas, que dela poderão deduzir a aplicação realizada no ensino fundamental de seus empregados e dependentes. (BRASIL, 1988) ${ }^{12}$

O texto acima mantém as ambiguidades apontadas ao longo de quase três décadas em relação ao salário-educação, o que vai prolongar as disputas pelos recursos públicos no ensino obrigatório por mais alguns anos.

Todas as demais leis, decretos e instrumentos sancionados e postos em vigor na década de oitenta tinham como objetivo aperfeiçoar a arrecadação, imprimir maior rigor à fiscalização e coibir fraudes e sonegações. Nenhuma grande alteração legal se produziu nos últimos anos da década. No entanto, as pressões decorrentes de movimentos deflagrados pela rede particular de ensino resultaram em medidas que foram estendendo, até o final da década, o atendimento aos chamados alunos da comunidade (alunos não empregados ou dependentes de empresas contribuintes e optantes do SME) já atendidos em 1983. Esses movimentos mobilizaram as redes particulares, em sua diferente composição - escolas confessionais, as chamadas comunitárias e as particulares não confessionais.

A década de noventa traz duas grandes alterações para a educação com impactos sobre a destinação do salário-educação. A primeira delas é a Emenda Constitucional $n^{0}$ 14, de 12 de setembro de 1996, que altera a Constituição de 1988 e acrescenta aspectos não contemplados nela. São eles:

12 Disponível em: http://www.planalto.gov.br/ccivil_03/constituicao/constituicao.htm 
a) permite a intervenção da União no Distrito Federal e nos Estados e destes nos Municípios em caso de não aplicação do mínimo das receitas de impostos na manutenção e desenvolvimento do ensino.

b) define, como dever do estado, a garantia de ensino fundamental obrigatório e gratuito e o estende àqueles que, na época própria, a ele não tiveram acesso;

c) compromete o Estado com a progressiva universalização do ensino médio;

d) atribui à União função redistributiva e supletiva como forma de garantir a equalização de oportunidades educacionais e padrão mínimo de qualidade;

e) determina, para os entes federados, a atuação prioritária em cada nível de ensino e formas de colaboração entre Estados e Municípios, visando garantir a universalização do ensino obrigatório;

f) altera o $\$ 5$ do artigo 212 que dispõe sobre o salário-educação. Diz ele: “O ensino fundamental público terá como fonte adicional de financiamento a contribuição social do salário-educação, recolhida pelas empresas na forma da lei." (BRASIL, 1996a)13

A nova redação torna compulsório o recolhimento do salário educação, retirando a alternativa de oferecimento de serviços educacionais próprios e/ou a oferta de bolsas para empregados e dependentes. Essa mudança altera a natureza jurídica do salário-educação - de contribuição social para tributo, por conta da EC n. 14/96, alterando o art. 212, $\$ 5^{\circ}$ da Constituição. O salário-educação, suprimindo a possibilidade de a empresa aplicar diretamente a contribuição em educação e tornando-a compulsória, deu a ele o caráter de tributo. Essa figura não se alterou com EC 53/o6.

Ela altera ainda, todo o art. 60 do Ato das Disposições Constitucionais Transitórias, trazendo, para o texto constitucional, percentuais de aplicação de recursos no ensino fundamental, determinando a criação de Fundos Estaduais e no Distrito Federal para manutenção e desenvolvimento do ensino fundamental, estabelece critérios para sua formação e para aplicação dos recursos (inclusive para o pagamento do magistério), define o papel da União na contribuição para os Fundos e

13 Disponível em: http://www.planalto.gov.br/ccivil_o3/constituicao/emendas/emc/emc14.htm 
para garantir valor mínimo nacional por aluno. Preconiza, no seu $\S 7^{\circ}$, que: "A lei disporá sobre a organização dos Fundos, a distribuição proporcional de seus recursos, sua fiscalização e controle, bem como a forma de cálculo do valor mínimo nacional por aluno."

Finalmente o texto constitucional, pelo menos no ensino fundamental, prioriza nitidamente o ensino público, redirecionando os recursos advindos de impostos e do salário-educação para a rede pública estadual ou municipal.

A segunda grande alteração legal da década também é do ano de 1996. Trata-se da Lei $n^{0}$ 9.424, de 24 de dezembro de 1996, a chamada lei do FUNDEF. Em relação ao salário-educação vale a pena reproduzir seu artigo 15 integralmente.

Art.15 - O salário-educação, previsto no art. 212, § 5º, da Constituição Federal e devido pelas empresas, na forma em que vier a ser disposto em regulamento, é calculado com base na alíquota de $2,5 \%$ (dois e meio por cento) sobre o total de remunerações pagas ou creditadas, a qualquer título, aos segurados empregados, assim definidos no art.12, inciso I da Lei $n^{0} 8.212$, de 24 de julho de 1991.

$\S 1^{\circ}$ A partir de $1^{\circ}$ de janeiro de 1997 , o montante da arrecadação do salárioeducação, após dedução de 1\% (um por cento) em favor do Instituto Nacional de Seguro Social - INSS, calculado sobre o valor, por ele arrecadado, será distribuído pelo Fundo Nacional de Desenvolvimento da Educação - FNDE, observada a arrecadação em cada Estado e no Distrito Federal, em quotas, da seguinte forma:

I - Quota Federal, correspondente a um terço do montante de recursos, que será destinada ao FNDE e aplicada no financiamento de programas e projetos voltados para a universalização do ensino fundamental, de forma a propiciar a redução dos desníveis sócio-educacionais existentes entre Municípios, Estados, Distrito Federal e regiões brasileiras;

II - Quota Estadual, correspondente a dois terços do montante de recursos, que será creditada mensal e automaticamente em favor das Secretarias de Educação dos Estados e do Distrito Federal para financiamento de programas, projetos e ações do ensino fundamental.

$\S 2^{\circ}$ Será distribuída $70 \%$ (setenta por cento) da Quota Estadual entre Estado e os respectivos Municípios, proporcionalmente ao número de alunos matriculados no ensino fundamental das respectivas redes, conforme censo educacional realizado pelo Ministério da Educação e do Desporto - MEC. (Dispositivo Vetado)

$\S 3^{\circ}$ Os alunos regularmente atendidos, na data da edição desta Lei, como beneficiários da aplicação realizada pelas empresas contribuintes, no ensino fundamental dos seus empregados e dependentes, à conta de deduções da contribuição social do salário-educação, na forma da legislação em vigor, terão, a partir de $1^{\circ}$ de janeiro de 1997, o benefício assegurado, respeitadas as condições em que foi concedido, e vedados novos ingressos nos termos do art.212,§ $5^{\circ}$ da Constituição Federal. (BRASIL, 1996b) ${ }^{14}$

14 Disponível em: http://www.planalto.gov.br/ccivil_03/LEIS/L9424.htm 
Assegurou-se, assim, o benefício dos alunos atendidos pelo Sistema de Manutenção de Ensino - SME; as empresas passam a recolher o salário-educação, como determina a lei, e aquelas que eram optantes do SME vão, paulatinamente, diminuindo os alunos assistidos até total extinção do sistema.

Depois dessas duas grandes alterações há ainda um razoável número de instrumentos legais dispondo sobre aspectos do salário-educação, mas merece destaque a Lei $\mathrm{n}^{0}$ 9766, de 18 de dezembro de 1998, porque, entre outros dispositivos, estabelece que, pelo menos 50\% da Quota Estadual será repartida proporcionalmente ao número de alunos matriculados no ensino fundamental, conforme apuração do censo escolar. Dispositivo semelhante havia sido vetado quando a Lei ${ }^{\circ}$ 9.424/96 foi sancionada. Embora o percentual seja menor, garante-se que parte da quota estadual chegue aos municípios que, em muitos casos, recebem a maioria do alunado.

Em 16 de agosto de 1999, o Decreto ${ }^{0} 3.142$ vai regulamentar a contribuição do salário-educação, tendo em vista o art. $212 \S 5^{\circ}$ da CF/88, o art. 15 da Lei no 9.424/96 e a Lei $n^{0}$ 9.766/98. Ele especifica o que se considera empregados, conforme definido pela Seguridade Social, com a finalidade de estabelecer inequivocamente a base de cálculo sobre a qual se fará o recolhimento do salário-educação. A importação desses conceitos de segurados da legislação específica amplia a base de cálculo, porque a legislação da Seguridade Social reflete e normatiza a complexidade das relações de trabalho no Brasil, nas últimas décadas, inclusive as relações advindas da terceirização de serviços. Para os contratos por tempo determinado, o Decreto diminui a alíquota para 1,25\%. Além disso estabelece rito procedimental para débitos de contribuições de salário-educação, levantados pelo FNDE.

Outros instrumentos legais do final da década de noventa e início dos anos 2000 não trazem alterações dignas de monta, a não ser a Lei ${ }^{\circ} 10.832$ de 29 de dezembro de 2003, alterando o art. $2^{\circ}$ da Lei $n^{\circ} 9.766 / 98$, que determina que toda a Quota Estadual e Municipal seja redistribuída entre o Estado e seus Municípios de forma proporcional ao número de alunos matriculados no ensino fundamental nas respectivas redes de ensino. Corrige-se assim uma distorção, obrigando os Estados a uma distribuição mais justa dos recursos.

Ainda em 2003 é sancionado o Decreto $n^{\circ}$ 4.943, de 30 de dezembro, que altera o Decreto 3.142, de 16/08/99. A principal alteração introduzida é a que obriga as 
empresas com folha de pagamento igual ou superior a dois milhões e quatrocentos mil reais no mês de dezembro de 2003, excluído o décimo terceiro-salário, a recolher a contribuição do salário-educação ao FNDE. Essa alteração parece vir para compensar a perda da arrecadação direta pelo FNDE, por conta da extinção completa do SME, que obrigava as empresas optantes a recolher à autarquia. Essa questão traz à tona discussão acerca do papel do FNDE na arrecadação do salário-educação, sua estrutura para tal tarefa, sua capilaridade para realizá-la e para fiscalizar as empresas em todo território nacional. Parece que esta é uma questão em discussão dentro do órgão e carente de decisão.

A modificação mais significativa ocorreu com a Lei $\mathrm{n}^{0} 11.494$, de 20 de junho de 2007, que regulamentou o Fundo de Manutenção e Desenvolvimento da Educação Básica e de Valorização dos Profissionais da Educação - FUNDEB, criado pela Emenda Constitucional $\mathrm{n}^{0} 53$, de 19 de dezembro de 2006, com vigência estabelecida para o período 2007-2020. A Lei mantém a destinação do salário-educação para o financiamento da educação pública, obrigatória e gratuita, mas na distribuição de recursos arrecadados propõe uma divisão diferente. Do total arrecadado e, descontada a taxa de 1\% devida ao órgão arrecadador, RFB, o restante está assim dividido:

I - 10\% do total destina-se ao FNDE, que os aplica no financiamento de projetos, programas e ações da educação básica;

II - Os 90\% restantes da arrecadação líquida são desdobrados e automaticamente disponibilizados aos respectivos destinatários, sob a forma de quotas, sendo:

a) quota federal - correspondente a 1/3 dos recursos, destinados ao FNDE, que os aplica no financiamento de programas e projetos voltados para a educação básica, com caráter redistributivo, de forma a propiciar a redução dos desníveis socioeducacionais entre os municípios, estados e regiões brasileiras;

b) quota estadual e municipal - correspondente a 2/3 dos recursos, creditados, mensal e automaticamente, em contas bancárias específicas das secretarias de educação dos estados, do Distrito Federal e dos municípios, na proporção do número de matrículas, para o financiamento de programas, projetos e ações voltados para a educação básica (art. 212, § $6^{\circ}$ da CF).

Sua implantação foi efetivada pelo Decreto $n^{0}$ 6.253, de 13 de novembro de 2007 , que regulamentou a Lei $n^{0}$ 11.494/2007, substituindo o Fundo de Manutenção e 
Desenvolvimento do Ensino Fundamental e de Valorização do Magistério (Fundef), que vigorou de 1998 a 2006.

Percorridas essas mais de cinco décadas de legislação acerca do salário-educação, certamente pode-se dizer que ele é um mecanismo de financiamento da educação, o mais duradouro deles, que veio para ficar.

\section{Salário-Educação - Resistências, Disputas e Desafios}

A criação do salário-educação ocorre num regime de exceção. Logo ele não é fruto de discussões e negociações com a sociedade civil e sequer com os setores organizados da economia, o que o faz ser corretamente percebido como uma imposição. Quanto à sua natureza de tributo ou não, desde o início pairou certa dúvida conceitual. O seu próprio formulador ora se refere a ele como tributo, ora como contribuição.

Era de se esperar, então, que sua implantação e cobrança provocassem resistências de toda ordem. Uma delas, a mais comum, se expressa na forma da sonegação pura e simples. Embora o professor Pasquale e muitos outros depois dele tenham apontado como difícil a sua sonegação, em razão de ele ser recolhido junto com outras contribuições incidentes sobre a folha de salários das empresas e não poder ser recolhido separadamente, o fato é que alguma sonegação ocorre.

Muitas são as empresas devedoras do INSS, o que motivou a promulgação de leis e decretos, ora apertando o cerco com mecanismos que dificultem a sonegação, ora estabelecendo critérios de parcelamentos de débitos, ora vetando às empresas devedoras de fornecerem ao governo e, sempre que as condições do mercado de trabalho se alteram, normatizando as relações para garantir que a base de cálculo inclua essas novas realidades.

Ao INSS sempre coube, além de arrecadar, fiscalizar as empresas; depois da criação do FNDE, a fiscalização passa a ser feita também por ele e parte da arrecadação, principalmente nos casos das empresas optantes do conhecido Sistema de Manutenção do Ensino (SME).

O Sistema de Manutenção do Ensino Fundamental (SME) constituiu uma forma alternativa de financiamento da educação mediante a qual as empresas contribuintes, ao optar pela participação nessa modalidade, deixavam de recolher a contribuição do 
salário-educação ao INSS para o recolherem ao FNDE. E o faziam utilizando guia específica, podendo, então, deduzir a aplicação realizada no ensino fundamental de seus empregados e dependentes em cinco modalidades diferentes: escola própria, aquisição de vagas, indenização de empregado, indenização de dependente, esquema misto.

Pela modalidade "escola própria" a empresa mantinha um estabelecimento de ensino a suas expensas, garantindo a oferta escolar a seus empregados e dependentes e, assim, podia deduzir do recolhimento mensal feito ao FNDE a importância correspondente ao número de escolares beneficiados. Essa importância era calculada levando em conta o valor fixado pelo Conselho Deliberativo do FNDE para a vaga ou bolsa. Respeitados os requisitos legais, outros alunos podiam ser atendidos nessa modalidade.

Na modalidade de aquisição de vagas, as empresas pagam as mensalidades na rede particular de ensino, com a mesma finalidade de assegurar o ensino fundamental a seus empregados e dependentes. Essa aquisição era intermediada pelo FNDE, sendo que a empresa recolhia ao FNDE a importância correspondente ao valor mensal, devido à contribuição do Salário-Educação.

A terceira possibilidade consistia na possibilidade de os empregados apresentarem à empresa o certificado de conclusão do ensino fundamental, via ensino supletivo e a empresa os reembolsar com a importância correspondente a doze meses o valor fixado para a vaga. E, então, a empresa podia capitalizar recursos correspondentes e deduzi-los dos recolhimentos mensais devidos ao FNDE.

Os empregados também tinham a possibilidade de declarar por escrito à empresa a frequência de seus dependentes em estabelecimentos de ensino não gratuito, bem como a quitação das respectivas mensalidades. Nesse caso, as empresas podiam reembolsá-los com a importância correspondente ao somatório dos valores da vaga vigente no respetivo semestre e, assim, capitalizar esses recursos e deduzi-los dos recolhimentos mensais devidos ao FNDE.

Finalmente, as empresas poderiam utilizar mais de uma das modalidades disponíveis.

Resultava desse sistema que cumpria ao FNDE a respectiva operacionalização, constituindo procedimentos diferenciados por se tratar de um programa de bolsas com 
características próprias e clientela específica. E isso requeria constantes ajustes feitos por meio de Resoluções do Conselho Deliberativo, estabelecendo e revendo normas, criando critérios de estabelecimento do número de vagas pelas empresas, proibindo indicação de beneficiários, além de certos limites, e assim por diante. Para a operacionalização no âmbito dos estados, o FNDE contava com as Delegacias do MEC (DEMECs), que oferecia orientações às escolas, às empresas e aos beneficiários do sistema, inclusive fazendo o acompanhamento e as fiscalizações necessárias.

Não tardou para o FNDE descobrir uma série de irregularidades no sistema de aquisição de vagas, com denúncias na imprensa, acerca da existência do que ficou conhecido como "bolsas fantasmas", aquelas em que empresas optantes, interessadas em não recolher, aliam-se ou não a escolas, e informam o atendimento a alunos que efetivamente não existem, no todo ou em parte.

A partir dessa constatação, em 1983 o FNDE reforçou a sua função fiscalizadora. Aperfeiçoaram-se os sistemas de coleta e controle de dados, houve maior articulação com as informações da Previdência e, principalmente, melhoria no sistema de informatização do FNDE.

Em 1993, pela Resolução $\mathrm{n}^{0} 15$ de outubro, o FNDE criou o Programa de Inspeção Integrado em Empresas e Escolas (Proinspe), destinado a acompanhar e controlar a participação das empresas optantes e das escolas credenciadas como prestadoras de serviço junto ao SME. A Resolução/CD/FNDE $n^{0}{ }^{19}$, de 5 de setembro de 2000, revoga a anterior, mas mantém a finalidade do programa, assim expressa em seu artigo $1^{\mathrm{o}}$ :

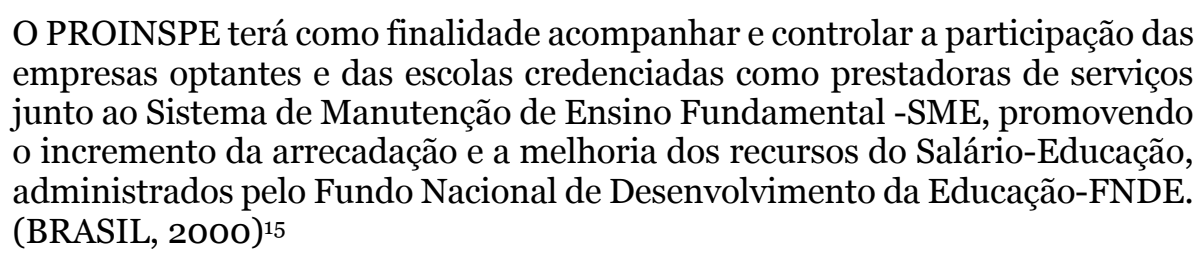

A execução do programa foi colocada a cargo das Secretarias de Educação, sob a gerência do FNDE, com a participação das respectivas Delegacias do MEC e do Conselho Nacional de Secretários de Educação (Consed).

15 Disponível em: ftp://ftp.fnde.gov.br/web/resolucoes_2000/res019_05092000.pdf 
A implantação do Proinspe desencadeou uma ação de inspeção que, no ano de 1994, analisou 1.488 empresas, 1.874 escolas participantes do SME, detectando irregularidades que levaram ao cancelamento do benefício da bolsa do salárioeducação a 10.906 alunos, representando uma economia de $\mathrm{R}$ 2,0 milhões, considerado o valor da bolsa vigente naquele momento.

Além do cancelamento de bolsas irregulares, o FNDE adotou medidas de ressarcimento de valores pagos indevidamente a escolas (com jutos, multa e correção monetária) mediante compensação, deduzindo o débito correspondente dos pagamentos posteriores ou notificando cobrança quando a primeira alternativa fosse contraindicada.

Em caso de irregularidades graves (falsificação de documentos, inclusão de alunos como beneficiários do sistema sem a correta identificação das empresas optantes, inclusão de alunos inexistentes, etc.) os contratos de prestação de serviços foram anulados, as escolas infratoras foram impedidas de se credenciarem no SME para o ano seguinte. E, por último, encaminhou-se comunicação à Polícia Federal localizadas nos respectivos estados para a adoção das providências cabíveis. Em casos menos graves, bastavam advertências ou multas, conforme os termos dos contratos firmados. E, finalmente, instaurou-se um sistema de orientação às empresas quanto às diferentes possibilidades de atendimento ao SME.

Para se ter uma ideia da complexidade da operacionalização é oportuno registrar que, nos termos do Decreto n. 87.043/82, o preço unitário mensal da vaga ou bolsa do SME deveria ser fixado trimestralmente pelo FNDE, e seu Conselho Deliberativo, tendo em vista a necessidade de manter o respetivo poder de compra e sem prejudicar a capacidade de geração de vagas pelas empresas contribuintes. E a realidade inflacionária pesava seriamente nessa atividade, e de tal sorte que no ano de 1994, o valor fixado em dezembro de 1993, tendo a Medida Provisória n. 434 criado a Unidade Real de Valor (URV), uma nova ordem legal passou a orientar o tratamento dispensado aos pagamentos das obrigações pecuniárias e o FNDE precisou fazer, no mês de março, um novo estudo para adequar o valor da bolsa ao novo ordenamento econômico-social para o primeiro trimestre e para os trimestres seguintes. Naquele ano o SME assegurava o ensino gratuito, mediante bolsa, a 827.192 alunos. 
Nesse período, o FNDE foi desafiado a criar, como informa o Relatório de 1989, uma área de cadastro de empresas junto ao SME, uma área de acompanhamento e controle da arrecadação, uma área de acompanhamento e controle do pagamento das escolas, uma área de apuração de débitos. E aumentou o peso interno do Setor de Dívida Ativa e arrecadação judicial, bem como as atividades de assessoramento jurídico-advocacia consultiva por parte da Procuradoria-Geral/Federal.

Na década de oitenta, em decorrência do Decreto $n^{\circ} 88.374$, de 7/6/83, que retirava do SME a possibilidade de atendimento, no sistema de bolsas, aos assim chamados alunos da comunidade, houve um movimento nacional liderado pela Federação Nacional dos Estabelecimentos de Ensino - FENEN pela sua revogação. O documento elaborado sob seus auspícios argumenta:

O Decreto $\mathrm{n}^{\circ} 88.374 / 83$, pela sua inoportunidade:

- obsta, na prática, a obediência aos preceitos constitucionais;

- revoga, por seus efeitos concretos, dispositivos da Lei 5692/71, da Reforma do Ensino;

- fere, inequivocamente, o espírito da Lei4.440/64, de criação do salárioeducação.

Em uma conjuntura de desemprego aberto e na qual cresceram enormemente as atividades autônomas- fora da CLT- configurando subemprego notório, o Decreto 88.374/83 impede que as empresas forneçam bolsas de estudos a filhos de desempregados e trabalhadores da chamada "economia invisível". O mesmo ocorrerá com filhos de militares, servidores públicos e funcionários da micro e macro-empresa, também fora do sistema do salário-educação. Talvez seja a gota d'água, mas fará transbordar o cálice de amargura de muitas famílias que necessitam do ensino gratuito.

Em instante tão grave, de perda considerável do poder aquisitivo das classes média e pobre, da extrema fragilidade econômica da livre iniciativa dedicada ao ensino, o Decreto 88.374/83 "muda as regras do jogo", redundando tudo isto em uma "combinação perversa", cujos efeitos assumem proporções calamitosas, condenando, de maneira brutal, a Escola Particular de $1^{\circ}$ grau, no Brasil, a morte vil e irremediável. (CORRÊA, 1984, p.3)

O movimento consegue sucessivos adiamentos da extinção do atendimento aos “alunos da comunidade" por meio do Decreto no 90.088/84 e outros com o mesmo fim, mas não consegue a revogação total do Decreto 88.374/83. Em 1989, os "alunos da comunidade” deixam de receber as bolsas financiadas pelo salário-educação das empresas optantes do SME.

Outra forma de reação ao instituto do salário-educação se manifesta no aumento gradativo de empresas isentas das contribuições sociais incidentes sobre a folha de salários, por serem organizações de assistência sem fins lucrativos. Quando 
foi instituído, em 1964, somente escolas, hospitais e entidades de assistência social sem fins lucrativos foram isentos.

Ao longo de todas essas décadas, certamente pressões de diversos setores conseguiram que a legislação fosse contemplando uma maior variedade de organizações isentas. Nesses casos tem se buscado garantir que essas organizações recebessem e tivessem de renovar, periodicamente, por meio de prestação de contas e inspeção, o Certificado de Fins Filantrópicos expedido pela seguridade social e dessem sua contrapartida em forma de bolsas.

O SME, no entanto, persistiu por toda década de noventa e, embora tenha, a partir de 1997, novos ingressos proibidos, só terminou em 2003. Pelo teor dos relatórios, se constituiu no grande calcanhar de Aquiles do FNDE e, indiscutivelmente, terá sido uma das grandes fontes de dor de cabeça para os dirigentes no seu desafio da correta captação dos recursos do salário-educação.

Outra expressão dessa inconformidade são as ações de inconstitucionalidade impetradas junto ao STF, questionando o instituto do salário-educação. Desde a década de setenta até os dias atuais são conhecidas várias delas e muitos processos administrativos instaurados pelo FNDE, por sonegação da contribuição, aduzem essa razão para a cessação do recolhimento.

O final dos anos 90 e começos dos anos 2000 foram de intensa atividade na esfera da Procuradoria-Geral, em especial, e da Auditoria Interna, em razão de um movimento ou onda de contestação, por parte das empresas, da exigibilidade da contribuição do salário-educação, especialmente a partir da aprovação da Lei n. 9.394/96, Lei de Diretrizes e Bases da Educação Nacional, cujos termos serviram de pretexto para a deflagração de ações. Tal situação vai serenar apenas a partir do ano de 2006, quando o Supremo Tribunal Federal definirá a questão em favor do FNDE. Na verdade, foi um longa disputa, iniciada no ano de 1989.

No entanto, apesar de todas as formas de resistências, dada a importância do salário-educação no financiamento do ensino fundamental, o volume de recursos aportados, o número e a dispersão das empresas no território nacional, tem-se que reconhecer, com o seu formulador, que se trata de contribuição de fácil recolhimento e difícil sonegação 
Quanto às disputas pelos recursos oriundos do salário-educação, elas surgem com a sua própria criação, na medida em que o texto legal diz que ele é "destinado a suplementar as despesas públicas com a educação elementar”, mas não restringe essas despesas ao sistema público de ensino. Haverá desde então disputa pelos recursos do salário-educação até que a $\mathrm{EC} \mathrm{n}^{0}{ }^{14} / 96$ determine a destinação exclusiva do salárioeducação.

\section{SALÁRIO-EDUCAÇÃO - A DIMENSÃo dOS RECURSOS}

O Salário Educação já completou 55 anos de efetiva implantação. Desde sua criação trazia a esperança de se tornar a mais importante fonte de financiamento do ensino primário, depois fundamental, obrigatório. Seu criador estimava que, já no seu primeiro ano de recolhimento, ele pudesse propiciar um incremento nas matrículas da ordem de 25\%. Sabe-se que de 1964, ano de sua criação, até hoje, a massa salarial sofreu expressiva expansão, pelo aumento do número de empresas tanto no setor industrial, comercial e de serviços e pela progressiva formalização dos contratos de trabalho, retirando da informalidade muitos trabalhadores e expandindo a base de cálculo do salário-educação. Essa expansão não ocorreu de forma contínua; muito antes teve um crescimento por ondas e com períodos de recessão, além de não abranger toda a atividade econômica do país, ainda com muitos empreendedores informais. No entanto é inegável que o país se industrializou cada vez mais, modernizou-se, urbanizou-se intensamente. Tudo isso com reflexos positivos no recolhimento do salário-educação.

Para que se possa - ao longo desses cinquenta e cinco anos, em que o país teve oito moedas diferentes - avaliar o comportamento da arrecadação e seu progressivo crescimento, é apresentada a tabela abaixo, em valores nominais, convertidos em reais, e percentual por ano e período quinquenal. A considerar a oscilação do valor do real ao longo desse período, em relação a moedas mais estáveis, cuja comparação excede o objetivo desse trabalho.

Tabela 1 - Arrecadação do salário-educação no período 1965-2019 


\begin{tabular}{|c|c|c|c|c|}
\hline \multirow[b]{2}{*}{ ANO } & \multicolumn{2}{|c|}{ ARRECADAÇÃO ANUAL } & \multicolumn{2}{|c|}{$\begin{array}{c}\text { ARRECADAÇÃO POR } \\
\text { QUINQUÊNIO }\end{array}$} \\
\hline & BILHỖS & \% CRESCIMENTO & BILHÔES & \% CRESCIMENTO. \\
\hline 1965 & 11,50 & - & \multirow{5}{*}{209,1} & \multirow{5}{*}{ - } \\
\hline 1966 & 25,80 & 124,30 & & \\
\hline 1967 & 51,40 & 99,20 & & \\
\hline 1968 & 55,50 & 8,00 & & \\
\hline 1969 & 64,90 & 16,90 & & \\
\hline 1970 & 69,80 & 7,60 & \multirow{5}{*}{449,5} & \multirow{5}{*}{$115,00 \%$} \\
\hline 1971 & 75,30 & 7,90 & & \\
\hline 1972 & 88,50 & 17,5 & & \\
\hline 1973 & 103,90 & 17,40 & & \\
\hline 1974 & 112,00 & 7,80 & & \\
\hline 1975 & 137,60 & 22,90 & \multirow{5}{*}{$1.324,8$} & \multirow{5}{*}{$194,70 \%$} \\
\hline 1976 & 209,80 & 52,50 & & \\
\hline 1977 & 253,40 & 20,80 & & \\
\hline 1978 & 331,10 & 18,80 & & \\
\hline 1979 & 392,90 & 0,20 & & \\
\hline 1980 & 461,80 & 17,50 & \multirow{5}{*}{$2.671,3$} & \multirow{5}{*}{$101,60 \%$} \\
\hline 1981 & 525,40 & 13,80 & & \\
\hline 1982 & 632,40 & 20,40 & & \\
\hline 1983 & 587,20 & $-7,10$ & & \\
\hline 1984 & 464,50 & $-20,90$ & & \\
\hline 1985 & 552,40 & 18,90 & \multirow{5}{*}{$3.988,70$} & \multirow{5}{*}{49,20} \\
\hline 1986 & $1.201,90$ & 117,60 & & \\
\hline 1987 & 793,80 & $-41,50$ & & \\
\hline 1988 & 556,80 & $-29,90$ & & \\
\hline 1989 & 883,80 & 58,70 & & \\
\hline 1990 & $2.077,20$ & 135,10 & \multirow{5}{*}{$7.650,70$} & \multirow{5}{*}{91,80} \\
\hline 1991 & $1.594,40$ & 30,30 & & \\
\hline 1992 & $1,468,30$ & $-7,90$ & & \\
\hline 1993 & $1.752,60$ & 19,30 & & \\
\hline 1994 & $2.226,50$ & 27,10 & & \\
\hline 1995 & $2.494,90$ & 12,10 & \multirow{5}{*}{$10.369,40$} & \multirow{5}{*}{35,50} \\
\hline 1996 & $2,778,50$ & 11,40 & & \\
\hline 1997 & $2.815,20$ & 1,30 & & \\
\hline 1998 & $2.647,10$ & $-6,00$ & & \\
\hline 1.999 & $2.412,20$ & $-8,90$ & & \\
\hline 2000 & $2.991,30$ & 24,00 & $18.611,80$ & 79,50 \\
\hline
\end{tabular}




\begin{tabular}{|c|c|c|c|c|}
\hline \multirow[b]{2}{*}{ ANO } & \multicolumn{2}{|c|}{ ARRECADAÇÃO ANUAL } & \multicolumn{2}{|c|}{$\begin{array}{l}\text { ARRECADAÇÃO POR } \\
\text { QUINQUÊNIO }\end{array}$} \\
\hline & BILHÕES & \% CRESCIMENTO & BILHÕ̃ES & \% CRESCIMENTO. \\
\hline 2001 & $3.123,30$ & 4,40 & & \\
\hline 2002 & $3.660,70$ & 17,20 & & \\
\hline 2003 & $4.005,20$ & 9,40 & & \\
\hline 2004 & $4.831,30$ & 20,60 & & \\
\hline 2005 & $5.913,60$ & 22,40 & \multirow{5}{*}{$38.584,30$} & \multirow{5}{*}{$125,70 \%$} \\
\hline 2006 & $6.965,40$ & 17,80 & & \\
\hline 2007 & $7 \cdot 156,30$ & 2,70 & & \\
\hline 2008 & $8.863,80$ & 23,90 & & \\
\hline 2009 & $9.685,19$ & 9,30 & & \\
\hline 2010 & $11.160,20$ & 15,20 & \multirow{5}{*}{$74 \cdot 548,50$} & \multirow{5}{*}{$93,20 \%$} \\
\hline 2011 & $13.246,00$ & 18,70 & & \\
\hline 2012 & $14.924,00$ & 12,70 & & \\
\hline 2013 & $16.731,10$ & 12.10 & & \\
\hline 2014 & $18.487,20$ & 10,50 & & \\
\hline 2015 & $19.279,10$ & 4,30 & \multirow{5}{*}{$102.278,20$} & \multirow{5}{*}{$37,20 \%$} \\
\hline 2016 & $19.715,90$ & 2,30 & & \\
\hline 2017 & $20.339,50$ & 3,20 & & \\
\hline 2018 & $22.087,80$ & 8,60 & & \\
\hline 2019 & $20.855,90$ & $-5,60$ & & \\
\hline TOTAIS & $258.702,90$ & 100 & $258.702,90$ & 100 \\
\hline
\end{tabular}

Fonte: Relatórios anuais FNDE/Darc/Dirof.

Como se vê, embora com variações, alguns picos (já expurgada a inflação) e recuos (isto deve ser atribuído às variações da atividade econômica), o salárioeducação teve crescimento contínuo, exatamente como previram seus formuladores. Nos anos 8o, em face do contexto de crise econômica que então se vivia, os valores oscilam sensivelmente. Partindo de uma arrecadação de R\$ 11.554,27, em 1965, alcança pouco mais que o dobro no ano seguinte, $\mathrm{R} \$ 25.825,36$ em 1966, e se aproxima dos 65 milhões em 1969, ao final dos primeiros 5 anos, um amento aproximado de 500\%. Essa evolução prosseguirá sempre, ou quase sempre, passando da casa de dezenas de milhões para a de centenas de milhões, a partir de 1973, saltando para a casa dos bilhões, a partir de 1990. Saltos, convenha-se, gigantescos.

A arrecadação de 1965 foi realizada com base na alíquota de 2\% do SalárioMínimo local, estipulada pela Lei no 4.440/64. De 1966 a 1975 a arrecadação foi 
realizada com base na alíquota de $1,4 \%$ do salário de contribuição, por força da Lei 4.863/65. A partir de 1976 a arrecadação passa a ser realizada com base na alíquota de 2,5\% do salário de contribuição, em consequência das alterações introduzidas pelo Decreto $1.422 / 75$.

A história da evolução da arrecadação bruta do Salário-Educação, porém, é também sugestiva da história de uma organização que aprende. Essa arrecadação aconteceu considerando a responsabilidade de duas instituições: o FNDE e o Iapas, depois transformado em INSS e, a partir de 2008, a transferência dessa atividade para a Receita Federal do Brasil (RFB).

A presença mais acintosa do FNDE no processo de arrecadação nos últimos 15 anos do século passado se devia ao fato de somente ele poder recolher a contribuição das empresas que optavam, nos termos legais, pela manutenção de seu próprio sistema de ensino fundamental, que vai constituir o SME.

$\mathrm{Na}$ realidade, a arrecadação foi atribuição do Iapas nos dez primeiros anos (1964-1974). Na década de 1975-1984, o FNDE passou a participar da arrecadação em escala crescente (iniciando com 16\% e chegando a 47\%). Nas duas décadas seguintes, de 1985 a 2004, passou a ser o principal arrecadador, com participação em torno de 60\%. Entre 2005 e 2007 o INSS e RFB passam a ter mais 50\% da arrecadação. Em 2007 a arrecadação ficou ainda por conta da Secretaria da Receita Previdenciária, enquanto se preparava a transferência para a RFB, de acordo com a Lei n. 11.457, de março de 2007. A partir de 2008, a arrecadação passou a ser feita pela RFB, ficando o FNDE apenas recebendo os valores de débitos parcelados, com previsão de encerramento definitivo no ano de 2018.

A história desse processo de arrecadação é reveladora dos desafios nele envolvidos. Ao longo de 20 anos o FNDE foi o principal responsável pela arrecadação, com todos os percalços nele envolvidos. A partir do ano de 1983, o FNDE começa a viver um grande sufoco porque, entre outras possíveis razões, era comum a queixa quanto à escassez do seu quadro de pessoal, seja em geral, seja nesse setor crucial da arrecadação.

Até meados da primeira década do século 21, a contribuição do salário representava a parcela majoritária do orçamento do FNDE. Em 2006 representou 63,40\%. Na medida em que o FNDE assumiu a gestão da participação da União no 
FUNDEB e no FIES, o orçamento do FNDE deu saltos gigantescos, saindo de perto de 10 bilhões para, aproximadamente 61 bilhões em 2017, com leve queda nos últimos dois anos, em função da redução de recursos do FIES. Em 2019, segundo o Relatório de Gestão do Portal do FNDE, o Salário Educação participou do orçamento do FNDE com 12,97 bilhões, correspondendo a 22,18\%, participação aproximada dos últimos anos.

A série histórica do salário educação, por si só, é eloquente. O crescimento vai se intensificando de tal forma que, em 1983, a Prof. Ecilda Ramos de Souza, numa conferência pronunciada no II Encontro de Técnicos da Secretaria da Cultura do MEC, afirma:

\begin{abstract}
Quando se fala, hoje, de Salário-Educação, do ponto de vista econômicofinanceiro, estamos falando da $5^{\mathrm{a}}$ arrecadação 'tributária' do país. Perdemos apenas para o IOF, para o IPI, para o Imposto de Renda e para a contribuição previdenciária. Foi esta uma longa luta, desde que ele foi criado em 64, sob a inspiração do Prof. Carlos Pasquale e sob o riso e a galhofa da tecnoburocracia daquele tempo. (SOUZA, 1983, p.1)
\end{abstract}

Incontestavelmente, a contribuição do salário-educação foi, por muito tempo, a galinha dos ovos de ouro do FNDE e do MEC.

\title{
Referências
}

BRASIL. Constituição (1988). Constituição da República Federativa do Brasil, 1988. Brasília: Senado Federal, Centro Gráfico, 1988. Disponível em:

http://www.planalto.gov.br/ccivil_o3/constituicao/constituicao.htm. Acesso em: 22 jul. 2020.

BRASIL. Constituição dos Estados Unidos do Brasil, de 10 de novembro de 1937. Rio de Janeiro: Imprensa Oficial, 1937. Disponível em: http://www.planalto. gov.br/ccivil_03/Constituicao/Constituicao37.htm. Acesso em: 22 jul. 2020.

BRASIL. Constituição dos Estados Unidos do Brasil, de 16 de julho de 1934. Rio de Janeiro: Imprensa Oficial, 1934. Disponível em: http://www.planalto.gov. br/ccivil_03/constituicao/constituica034.htm. Acesso em: 22 jul. 2020.

BRASIL. Constituição dos Estados Unidos do Brasil, de 18 de setembro de 1946. Rio de Janeiro: Imprensa Oficial, 1946. Disponível em: http://www.planalto. gov.br/ccivil_03/constituicao/constituica046.htm. Acesso em: 22 jul. 2020. 
BRASIL. Decreto-Lei no $\mathbf{5 \cdot 4 5 2}$, de $1^{0}$ de maio de 1943. Aprova a Consolidação das Leis do Trabalho. Rio de Janeiro: Imprensa Oficial, 1943. Disponível em: http://www.planalto.gov.br/ccivil_03/decreto-lei/del5452.htm. Acesso em: 22 jul. 2020.

BRASIL. Decreto-Lei no. 872, de 15 de setembro de 1969. Complementa disposições da Lei número 5.537, de 21 de novembro de 1968, e dá outras providências. Brasília: Imprensa Oficial, 1969. Disponível em: http://www.pla nalto.gov.br/ccivil_03/Decreto-Lei/1965-1988/Delo872.htm. Acesso em: 22 jul. 2020.

BRASIL. Emenda Constitucional no 14, de 12 de setembro de 1996. Modifica os arts. 34, 208, 211 e 212 da Constituição Federal e dá nova redação ao art. 60 do Ato das Disposições Constitucionais Transitórias. Brasília: Diário Oficial da União, 1996. Disponível em: http://www.planalto.gov.br/ccivil_03/constituicao/emen das/emc/emc14.htm. Acesso em: 23 jul. 2020.

BRASIL. Emenda Constitucional no . 24, de $1^{\circ}$ de dezembro de 1983. Estabelece a obrigatoriedade de aplicação anual, pela União, de nunca menos de treze por cento, e pelos Estados, Distrito Federal e Municípios, de, no mínimo, vinte e cinco por cento da renda resultante dos impostos, na manutenção e desenvolvimento do ensino. Brasília: Imprensa Oficial, 1983b. Disponível em: https://bit.ly/em24-1983. Acesso em: 22 jul. 2020.

BRASIL. Lei no . 4.440, de 27 de outubro de 1964. Institui o Salário-Educação e dá outras providências. Brasília: Imprensa Oficial, 1964. Disponível em: https://bit.ly/lei4440. Acesso em: 22 jul. 2020.

BRASIL. Lei no ${ }^{\mathbf{5}}$.692, de 11 de agosto de 1971. Fixa Diretrizes e Bases para o ensino de $1^{\circ}$ e $2^{\circ}$ graus, e dá outras providências. Brasília: Imprensa Oficial, 1971. Disponível em: https://bit.ly/lei5692. Acesso em: 22 jul. 2020.

BRASIL. Lei no $\mathbf{7 \cdot 3 4 8}$, de 24 de julho de 1985. Dispõe sobre a execução do $\S 4^{0}$ do art. 176 da Constituição Federal, e dá outras providências. Brasília: Diário Oficial da União, 1985. Disponível em https://bit.ly/l7348_1985. Acesso em: 22 jul. 2020.

BRASIL. Lei no . 9.424, de 24 de dezembro de 1996. Dispõe sobre o Fundo de Manutenção e Desenvolvimento do Ensino Fundamental e de Valorização do Magistério, na forma prevista no art. 60, $\S 7^{\circ}$, do Ato das Disposições Constitucionais Transitórias, e dá outras providências. Brasília: Diário Oficial da União, 1996b. Disponível em: http://www.planalto.gov.br/ccivil_o3/LEIS/ L9424.htm. Acesso em: 23 jul. 2020.

BRASIL. Ministério da Educação e Cultura. Conselho Federal de Educação. Parecer N. 2.o71, de 6 de julho de 1976. Possibilidade de serem repassados, aos municípios 
que se encarregarem totalmente do ensino de $1^{0}$ grau, os recursos oriundos do Salário-Educação. Relator: Esther de Figueiredo Ferraz. Documenta, Brasília, n.188, p. 37-40, jul. 1976.

BRASIL. Ministério da Educação. Resolução/CD/FNDE no • o19, de 05 de setembro de 2000. Dispõe sobre o PROINSPE e dá outras providências. Brasília: Ministério da Educação, 2000. Disponível em: ftp://ftp.fnde.gov.br/web/resolu coes_2000/res019_05092000.pdf. Acesso em: 23 jul. 2020.

CORREAA, Arlindo Lopes. A Questão do Salário-Educação. Brasília: FENEN, 1984 .

FÁVERO, Maria de Lourdes de Albuquerque, e BRITTO, Jader de Medeiros. Dicionário de Educadores no Brasil: Da Colônia aos Dias Atuais. Rio de Janeiro : Editora UFRJ; Brasília : MEC/INEP, 1999.

FUNDO NACIONAL DE DESENVOLVIMENTO DA EDUCAÇÃO. “Bolsas Fantasmas”: esclarecimentos à opinião pública. Brasília: FNDE, [1984?].

FUNDO NACIONAL DE DESENVOLVIMENTO DA EDUCAÇÃO. "SME ALUNOS DA COMUNIDADE": estratégia de absorção pelos sistemas locais em 1985. Brasília: FNDE, [1985?].

FUNDO NACIONAL DE DESENVOLVIMENTO DA EDUCAÇÃO. Financiamento da educação, Cultura e Desportos: uma tentativa de abordagem do problema. Brasília: FNDE, [1983?].

FUNDO NACIONAL DE DESENVOLVIMENTO DA EDUCAÇÃO. Financiamento reembolsável. Brasília: FNDE, [1985?].

FUNDO NACIONAL DE DESENVOLVIMENTO DA EDUCAÇÃO. Legislação: salário-educação. Brasília: FNDE, 2002.

FUNDO NACIONAL DE DESENVOLVIMENTO DA EDUCAÇÃO. O SalárioEducação: sua história e sua aplicação. Brasília: FNDE, 1979.

FUNDO NACIONAL DE DESENVOLVIMENTO DA EDUCAÇÃO. Relatório do Grupo de Trabalho criado pela Portaria Ministerial no 81/83, com proposta de revisão da sistemática do Salário-Educação. Brasília: FNDE, [1983?].

FUNDO NACIONAL DE DESENVOLVIMENTO DA EDUCAÇÃO. SalárioEducação. [Brasília]: FNDE, 1989. 
FUNDO NACIONAL DE DESENVOLVIMENTO DA EDUCAÇÃO. SalárioEducação: Sistema de Manutenção de Ensino de $1^{\circ}$ Grau - SME. Brasília: FNDE, 1993.

FUNDO NACIONAL DE DESENVOLVIMENTO DA EDUCAÇÃO. SalárioEducação: aperfeiçoamento do processo de arrecadação. Brasília: FNDE, 1984.

FUNDO NACIONAL DE DESENVOLVIMENTO DA EDUCAÇÃO. SalárioEducação: atualização da legislação. Brasília: FNDE, [1981?].

FUNDO NACIONAL DE DESENVOLVIMENTO DA EDUCAÇÃO. “Quota Municipal” do Salário-Educação: notas para um estudo. Brasília: FNDE, [1983?].

MELCHIOR, José Carlos de Araújo. O Financiamento da Educação no Brasil: algumas questões atuais. Em Aberto, Brasília, ano 2, n. 14, p. 1-11, abr. 1983.

PASQUALE, Carlos. Desenvolvimento do ensino primário e o Plano Nacional de Educação. Revista Brasileira de Estudos Pedagógicos, Rio de Janeiro, v. 45, n.102, p. 185-235, abr./jun. 1966.

PASQUALE, Carlos. O que é salário-educação? Como funciona o sistema. MEC, Rio de Janeiro, ano 7, n. 29, p. 15-24, jan./fev. 1965.

SILVA, Bruno Matos e. Da constitucionalidade do Salário-Educação. Tribuna do Direito, São Paulo, jun. 1998. Disponível em:<http://www.brunosilva.adv.br/saledu.htm >. Acesso em: 21 fev. 2006.

SOUZA, Ecilda Ramos. O Salário-Educação não é a "educação" do salário. In: ENCONTRO DE TÉCNICOS DA SECRETARIA DA CULTURA/MEC - PROJETO "INTERAÇÃO ENTRE EDUCAÇÃO BÁSICA E OS DIFERENTES CONTEXTOS CULTURAIS EXISTENTES NO PAÍS”, 2., 1983, [Brasília]. Anais... [Brasília]: FNDE, 1983. f.1-46. Palestra.

VELOSO, Fábio. Salário-educação e o financiamento da educação primária. Revista Brasileira de Estudos Pedagógicos, Rio de janeiro, v. 54, p. 189-203, jul./set. 1970 .

\section{Sobre os autores}

\section{Carlos Roberto Jamil Cury}

Doutor em Educação e Professor do Programa de Pós-graduação em Educação da PUC Minas. E-mail: crjcury.bh@terra.com.br 


\section{Genuíno Bordignon}

Professor aposentado da UNB Mestre em Educação e foi diretor da Faculdade de Educação da UNB. E-mail: genuino.bordignon@gmail.com 